\title{
A COMPARATIVE CLINICAL STUDY OF INTRAARTICULAR CLONIDINE V/S DEXMEDETOMIDINE IN ARTHROSCOPIC KNEE SURGERIES (ACL REPAIR) FOR POSTOPERATIVE ANALGESIA
}

\author{
Basavaraj Patil1, Shivanand Karigar ${ }^{2}$, D. G. Talikoti ${ }^{3}$ \\ ${ }^{1}$ Assistant Professor, Department of Anaesthesia, BLDEU Shri B. M. Patil Medical College, Vijaypur, Karnataka, India. \\ ${ }^{2}$ Assistant Professor, Department of Anaesthesia, BLDEU Shri B. M. Patil Medical College, Vijaypur, Karnataka, India. \\ 3Professor and HOD, Department of Anaesthesia, BLDEU Shri B. M. Patil Medical College, Vijaypur, Karnataka, India.
}

\section{ABSTRACT}

\section{BACKGROUND}

Both clonidine and dexmedetomidine morphine (Both a2 agonists) provide enhanced patient analgesia after arthroscopic knee surgeries when administered via intraarticular route.

\section{OBJECTIVES}

To compare the duration of post-operative analgesia of clonidine and dexmedetomidine when administered intraarticularly as well as haemodynamic stability after arthroscopic knee surgeries.

\section{METHODOLOGY}

This is a randomized trial study involving 40 pts. of ASA grade 1 and 2 of aged between 18 and 60 yrs. Patients were divided randomly into two groups as group $C(n=20)$ and group $D(n=20)$. After arthroscopic knee surgeries, postoperative pain was measured by VAS score at 0,30 mins, 60 mins, 90 mins, 120 mins and then every 2 hrly up to 24 hrs. Side effects and vital signs were also noted. Duration of analgesia was noted in each case as when VAS score $\geq 3$.

\section{RESULTS}

Mean duration of analgesia in postoperative period in group D was $18.4 \mathrm{hrs} . \pm 4.95$ and in group C $15.1 \mathrm{hrs} . \pm 2.71$. Differences in duration of analgesia was statistically significant $(\mathrm{P}<0.05)$ when compared by student ' $\mathrm{t}$ ' test. VAS scores were also lower in group D compared to group at 6, 8, 10,12,14, 16, 18, 20, 22, 24 hrs. postoperative period. No major side effects were noted in both groups in dosages used.

\section{CONCLUSION}

Dexmedetomidine produced more prolonged post-operative analgesia (mean $18.4 \mathrm{hrs}$.) than clonidine (mean $15.1 \mathrm{hrs}$.), which is statistically significant $(\mathrm{P}<0.05)$. No major side effects were noted in both groups in clinically used dosages.

\section{KEYWORDS}

Arthroscopic Knee Surgery, Intraarticular Injection Clonidine, Dexmedetomidine, Post-Operative Analgesia.

HOW TO CITE THIS ARTICLE: Patil B, Karigar S, Talikoti DG. A comparative clinical study of intraarticular clonidine v/s dexmedetomidine in arthroscopic knee surgeries (ACL repair) for postoperative analgesia. J. Evolution Med. Dent. Sci. 2016;5(53): 3536-3539, DOI: 10.14260/jemds/2016/815

\section{INTRODUCTION}

Arthroscopic knee surgery is one of the most common minimally invasive surgical procedures in modern orthopaedic setup. Knee arthroscopy is very often performed as day-case surgery. It seems that ambulatory arthroscopic surgery of the knee is preferred by the majority of properly selected and well informed patients. ${ }^{1}$ It has been reported that a significant number of patients have moderate-to-severe pain 24 hours after ambulatory surgery in general and knee arthroscopy in particular and pain affects the patient's activity level and satisfaction. ${ }^{2,3}$ In an effort to provide an effective, safe and long-lasting post-arthroscopy analgesia, several studies using different drugs and regimes have been published during the last two decades.

Financial or Other, Competing Interest: None.

Submission 09-06-2016, Peer Review 21-06-2016,

Acceptance 24-06-2016, Published 04-07-2016.

Corresponding Author:

Shivanand Karigar,

Assistant Professor

Department of Anaesthesia,

BLDEU Shri B. M. Patil Medical College,

Vijaypur.

E-mail: shivanandkarigar82@gmail.com

DOI: $10.14260 /$ jemds $/ 2016 / 815$
Previous studies with intraarticular ropivacaine. 4 , fentanyl. ${ }^{5}$ and dexmedetomidine. 6 had proved their efficacy in providing postoperative analgesia in arthroscopic knee surgery. Dexmedetomidine is highly selective (Eight times more selective than clonidine). ${ }^{7}$ specific and potent; $\alpha 2$ adrenergic agonist has analgesic, sedative, antihypertensive and anaesthetic sparing effects when used in a systemic route. ${ }^{8}$ In the present study, we used dexmedetomidine intraarticularly in dose of $100 \mathrm{mcg}$ post arthroscopy.

Clonidine, an $\alpha 2$ agonist also has a peripheral analgesic effect. 9 Intraarticular bupivacaine provides enhanced postoperative analgesia after arthroscopic knee surgeries. ${ }^{10}$ The addition of either dexmedetomidine or clonidine to intraarticular bupivacaine improves postoperative analgesia compared with either drug alone. ${ }^{11}$

The primary objective of this study was to compare the duration of analgesic effects and haemodynamic stability of dexmedetomidine and clonidine when administered intraarticularly after arthroscopic knee surgeries.

\section{MATERIALS AND METHODS}

After Institutional Review Board approval, informed written consent was obtained from 40 pts. scheduled to undergo 
elective arthroscopic knee ACL repair in BLDEUs Shri B. M. Patil Medical College and Hospital, Vijaypur.

Patients eligible for participation were aged between 18 to $60 \mathrm{yrs}$. and were ASA physical status 1 and 2. Patients excluded had a contraindication to use of clonidine or dexmedetomidine or local anaesthetics.

Patients were randomly divided into two groups as group $D(n=20)$ and group C $(n=20)$. All patients of both groups were premedicated with Inj. Glycopyrrolate $0.2 \mathrm{mg}$ IV and Inj. midazolam $1 \mathrm{mg}$ IV. After placement of all routine monitors (NIBP, SPO2, ECG), all vitals were recorded before and after premedication. All pts. in both groups were induced under spinal anaesthesia with Inj. bupivacaine heavy $0.5 \%, 3 \mathrm{~mL}$ under all aseptic and antiseptic precautions. Temp, pulse, BP, SPO2 were monitored throughout intraoperative period at 0 , 30, 60, 90 mins.

After completion of the surgery, the patients were given following drugs intraarticularly through arthroscopic port depending on group.

Group D received Inj. dexmedetomidine $100 \mathrm{mcg}+$ Inj. bupivacaine $0.25 \%, 20 \mathrm{~mL}$.

Group C received Inj. clonidine $100 \mathrm{mcg}+$ Inj. bupivacaine $0.25 \%, 20 \mathrm{~mL}$.

All vitals like temperature, pulse, BP and VAS score for pain were monitored and recorded postoperative at $0,30,60,90$, 120 mins and thereafter 2 hrly upto $24 \mathrm{hrs}$. All patients were instructed preoperatively in the use of the $10-\mathrm{cm}$ Visual Analogue Scale (VAS) for pain, $0=$ no pain to $10=$ the worst imaginable pain. Demographic data were analysed by using analysis of variance.

Duration of analgesia was recorded as VAS score $\geq 3$ in the postop period. The side effects or complications if any are also noted in postoperative period. Total duration of analgesia of both the groups were compared by using student's ' $t$ ' test.

\section{Statistical Analysis}

The data was analysed using Microsoft Excel software. Descriptive statistics was used to analyse the data. Chi-square test was used to find out the association.

\section{RESULTS}

\begin{tabular}{|c|c|c|c|}
\hline & $\begin{array}{c}\text { Group D } \\
(\mathbf{n = 2 0 )} \\
\text { Mean } \pm \text { SD }\end{array}$ & $\begin{array}{c}\text { Group C } \\
(\mathbf{n = 2 0 )} \\
\text { Mean } \pm \text { SD }\end{array}$ & $\begin{array}{c}\text { P } \\
\text { value }\end{array}$ \\
\hline Mean age (yrs.) & $37.4 \pm 9.5$ & $36.1 \pm 8.644$ & $>0.05$ \\
\hline Mean wt (kg) & $63.55 \pm 3.1$ & $63.33 \pm 2.75$ & $>0.05$ \\
\hline $\begin{array}{c}\text { Sex } \\
\text { (Male: Female) }\end{array}$ & $10: 10$ & $12: 08$ & $>0.05$ \\
\hline ASA Grade 1:2 & $8: 12$ & $8: 12$ & $>0.05$ \\
\hline $\begin{array}{c}\text { Mean Duration of } \\
\text { Surgery (min) }\end{array}$ & $65 \pm 8.5$ & $70 \pm 6.5$ & $>0.05$ \\
\hline \multicolumn{3}{|c|}{ Table 1: Demographic Data of Both Groups } \\
\hline
\end{tabular}

There were no significant differences between the two groups with respect to age, sex, weight or the duration of surgery. No patient experienced hypotension (Mean arterial pressure $<20 \%$ of baseline), hypoxaemia (Sp02 <90\%) or bradycardia (heart rate $<60 \mathrm{bpm}$ ). No pt. complained of sedation or other side effects. The differences were statistically not significant $(\mathrm{P}>0.05)$.

\begin{tabular}{|c|c|c|c|}
\hline & $\begin{array}{c}\text { Group D } \\
\text { (N=20) }\end{array}$ & $\begin{array}{c}\text { Group C } \\
\text { (N=20) }\end{array}$ & P value \\
\hline $\begin{array}{c}\text { Before } \\
\text { premedication }\end{array}$ & $84.2 \pm 5.85$ & $81 \pm 4.72$ & 0.0608 \\
\hline $\begin{array}{c}\text { After } \\
\text { premedication }\end{array}$ & $83.5 \pm 4.24$ & $81.9 \pm 3.75$ & 0.3338 \\
\hline $\begin{array}{c}\text { Intraoperative } 0 \\
\text { min }\end{array}$ & $82.05 \pm 4.23$ & $80.3 \pm 4.91$ & 0.2351 \\
\hline 30 mins & $82.1 \pm 4.24$ & $79.7 \pm 3.96$ & 0.2448 \\
\hline 60 mins & $81.4 \pm 5.64$ & $79.7 \pm 3.90$ & 0.42528 \\
\hline $\begin{array}{c}\text { Post-operative } 0 \\
\text { min }\end{array}$ & $81.7 \pm 6.74$ & $79.4 \pm 4.5$ & 0.3030 \\
\hline 30 mins & $80.5 \pm 6.80$ & $79.3 \pm 4.95$ & 0.52901 \\
\hline 60 mins & $81.9 \pm 6.78$ & $78.4 \pm 4.38$ & 0.06147 \\
\hline 90 mins & $81 \pm 6.24$ & $78 \pm 3.72$ & 0.07450 \\
\hline 2 hrs. & $80.6 \pm 6.39$ & $77.9 \pm 4.02$ & 0.1198 \\
\hline 4 hrs. & $80.7 \pm 6.19$ & $78 \pm 5.23$ & 0.1450 \\
\hline 6 hrs. & $80.6 \pm 6.68$ & $78.1 \pm 3.5$ & 0.1484 \\
\hline 8 hrs. & $80.9 \pm 6.56$ & $78.9 \pm 2.75$ & 0.2179 \\
\hline 10 hrs. & $80.1 \pm 5.48$ & $78.3 \pm 3.13$ & 0.21222 \\
\hline 12 hrs. & $80.1 \pm 5.36$ & $78.6 \pm 4.35$ & 0.3384 \\
\hline 14 hrs. & $80 \pm 5.31$ & $78 \pm 4.40$ & 0.2028 \\
\hline 16 hrs. & $81.4 \pm 5.12$ & $76.7 \pm 3.96$ & $\begin{array}{c}0.002077 \\
<0.05\end{array}$ \\
\hline 18 hrs. & $80.9 \pm 5.01$ & $76.5 \pm 4.53$ & $\begin{array}{c}0.00475 \\
<0.05\end{array}$ \\
\hline 20 hrs. & $81.6 \pm 4.75$ & $77.3 \pm 4.78$ & $\begin{array}{c}0.003625 \\
<0.05\end{array}$ \\
\hline 22 hrs. & $80.6 \pm 4.5$ & $77.5 \pm 5.01$ & $\begin{array}{c}0.03853 \\
<0.05\end{array}$ \\
\hline 24 hrs. & $80.7 \pm 4.40$ & $76.5 \pm 4.85$ & $\begin{array}{c}0.0046 \\
<0.05\end{array}$ \\
\hline Table 2: Mean Pulse Rate Per Minute of Both Groups \\
\hline
\end{tabular}

The above table shows mean pulse rates of group D and group C; statistically there is no significant difference between these two groups up to 14 hrs. postoperatively, but at 16,18 , $20,22,24 \mathrm{hrs}$. there is statistically significant difference observed $(\mathrm{p}<0.05)$ that is group $C$ show lower mean pulse rates than group $\mathrm{D}$.

\begin{tabular}{|c|c|c|c|}
\hline & $\begin{array}{c}\text { Group D } \\
(\mathrm{N}=20)\end{array}$ & $\begin{array}{c}\text { Group C } \\
(\mathrm{N}=20)\end{array}$ & $P$ value \\
\hline $\begin{array}{c}\text { Before } \\
\text { premedication }\end{array}$ & $96.36 \pm 4.85$ & $95.2 \pm 5.44$ & 0.4837 \\
\hline $\begin{array}{c}\text { After } \\
\text { premedication }\end{array}$ & $95.46 \pm 3.79$ & $95.7 \pm 4.09$ & 0.8528 \\
\hline $\begin{array}{l}\text { Intraoperative } \\
0 \mathrm{~min}\end{array}$ & $94.33 \pm 3.01$ & $93 \pm 4.27$ & 0.26229 \\
\hline 30 mins & $91.8 \pm 3.60$ & $90.33 \pm 4.94$ & 0.29123 \\
\hline 60 mins & $92.93 \pm 3.01$ & $90.36 \pm 5.12$ & 0.06301 \\
\hline $\begin{array}{c}\text { Post-operative } \\
0 \text { min }\end{array}$ & $93.06 \pm 3.34$ & $90.66 \pm 5.33$ & 0.0979 \\
\hline 30 mins & $92.33 \pm 3.94$ & $90.33 \pm 4.87$ & 0.16239 \\
\hline 60 mins & $92.64 \pm 3.71$ & $91 \pm 4.6$ & 0.2193 \\
\hline 90 mins & $92.9 \pm 2.87$ & $92.5 \pm 3.2$ & 0.1493 \\
\hline 2 hrs. & $93.33 \pm 2.97$ & $93.02 \pm 3.4$ & 0.0860 \\
\hline $4 \mathrm{hrs}$. & $93.9 \pm 2.86$ & $93.3 \pm 3.01$ & 0.05418 \\
\hline $6 \mathrm{hrs}$. & $93.43 \pm 3.47$ & $91.8 \pm 3.25$ & 0.305 \\
\hline 8 hrs. & $93.76 \pm 3.72$ & $92 \pm 3.5$ & 0.0130 \\
\hline $10 \mathrm{hrs}$. & $92.63 \pm 2.97$ & $91.89 \pm 3.01$ & 0.5073 \\
\hline $12 \mathrm{hrs}$. & $93.13 \pm 3.17$ & $92.9 \pm 3.20$ & 0.454 \\
\hline $14 \mathrm{hrs}$. & $93.43 \pm 4.53$ & $93.13 \pm 3.78$ & 0.1358 \\
\hline $16 \mathrm{hrs}$. & $93.73 \pm 3.10$ & $91.9 \pm 3.20$ & 0.029118 \\
\hline $18 \mathrm{hrs}$. & $93.33 \pm 3.68$ & $93.10 \pm 3.75$ & 0.2290 \\
\hline $20 \mathrm{hrs}$. & $93.13 \pm 4.43$ & $92.9 \pm 4.15$ & 0.2855 \\
\hline 22 hrs. & $93.1 \pm 3.54$ & $92.88 \pm 4.01$ & 0.6633 \\
\hline $24 \mathrm{hrs}$. & $93.76 \pm 2.89$ & $93.5 \pm 3.01$ & 0.0089 \\
\hline
\end{tabular}

Table 3: Mean Arterial Pressure ( $\mathrm{mmHg}$ ) of Both Groups 
The above table confers that mean arterial pressures of both the groups are comparable and there is no significant difference between the groups with regard to mean arterial pressure.

\begin{tabular}{|c|c|c|c|}
\hline & $\begin{array}{c}\text { Group D } \\
\text { Mean } \pm \text { SD }\end{array}$ & $\begin{array}{c}\text { Group C } \\
\text { Mean } \pm \text { SD }\end{array}$ & $P$ value \\
\hline 0 min & 0 & 0 & \\
\hline 30 mins & 0 & 0 & \\
\hline 60 mins & 0 & 0 & \\
\hline 90 mins & 0 & 0 & \\
\hline 2 hrs. & 0 & $0.1 \pm 0.307$ & 0.1625 \\
\hline 4 hrs. & 0 & $0.4 \pm 0.57$ & $\begin{array}{l}0.0075 \\
<0.05\end{array}$ \\
\hline 6 hrs. & 0 & $0.65 \pm 0.58$ & 8.8720 \\
\hline 8 hrs. & $0.2 \pm 0.41$ & $1.05 \pm 0.75$ & $\begin{array}{c}0.00013 \\
<0.05\end{array}$ \\
\hline $10 \mathrm{hrs}$. & $0.4 \pm 0.502$ & $1.5 \pm 0.68$ & 1.57496 \\
\hline $12 \mathrm{hrs}$. & $0.8 \pm 0.615$ & $2.05 \pm 0.82$ & 4.3318 \\
\hline 14 hrs. & $1.55 \pm 0.604$ & $2.35 \pm 0.81$ & $\begin{array}{c}0.001178 \\
<0.05\end{array}$ \\
\hline $16 \mathrm{hrs}$. & $2.3 \pm 0.571$ & $3.05 \pm 0.686$ & $\begin{array}{c}0.00059 \\
<0.05\end{array}$ \\
\hline $18 \mathrm{hrs}$. & $2.75 \pm 0.55$ & $3.5 \pm 0.76$ & $\begin{array}{c}0.00106 \\
<0.05\end{array}$ \\
\hline 20 hrs. & $3.15 \pm 0.74$ & $4 \pm 0.56$ & $\begin{array}{c}0.00025 \\
<0.05\end{array}$ \\
\hline 22 hrs. & $3.85 \pm 0.745$ & $4.75 \pm 0.71$ & $\begin{array}{c}0.00038 \\
<0.05\end{array}$ \\
\hline $24 \mathrm{hrs}$. & $4.55 \pm 0.60$ & $5.35 \pm 0.67$ & $\begin{array}{c}0.003210 \\
<0.05\end{array}$ \\
\hline
\end{tabular}

The above table shows mean VAS scores of both groups in post-operative period. It is evident that mean VAS score of group D was lower than the group C. Statistically significant was observed in group $\mathrm{D}$ at postoperative period at $4 \mathrm{hrs}$. $(\mathrm{p}<0.05), 8$ hrs. $(\mathrm{p}<0.05), 14 \mathrm{hrs} .(\mathrm{p}<0.05)$, and then up to 24 hrs.

\begin{tabular}{|c|c|c|c|}
\hline & $\begin{array}{c}\text { Group D } \\
\text { Mean } \pm \text { SD }\end{array}$ & $\begin{array}{c}\text { Group C } \\
\text { Mean } \pm \text { SD }\end{array}$ & P value \\
\hline $\begin{array}{c}\text { Duration } \\
\text { (HRS.) }\end{array}$ & $18.4 \pm 4.958$ & $15.1 \pm 2.712$ & $\begin{array}{c}0.0003 \\
<0.05\end{array}$ \\
\hline \multicolumn{3}{|c|}{ Table 5: Total Mean Duration of Post-Operative } \\
Analgesia (VAS $\geq 3$ ) in Both Groups (Hours)
\end{tabular}

The above table shows that mean duration of postoperative analgesia was longer in group D, i.e. $18.4 \mathrm{hrs}$., while that of group C was $15.1 \mathrm{hrs}$.

The difference between the two groups was significant with regard to postop duration of analgesia when it is tested by student's ' $t$ ' test. Postoperative analgesia duration was considered when VAS score $\geq 3$ in postoperative period. The $p$ value is 0.0003 , which is significant.

\section{DISCUSSION}

There is a drive towards day surgery for arthroscopic Anterior Cruciate Ligament (ACL) reconstruction. The increasing pressure on beds, incidence of hospital acquired infection and financial implications are some of the factors fuelling this trend. Despite the increase in the number of outpatient surgical procedures, one of the limiting factors is the adequate understanding and management of post-operative pain. ${ }^{4}$

There are no studies that closely examined the pattern of analgesia consumption and pain in the first 16 to 20 hours after surgery. Furthermore, the considerable inter-patient variability in postoperative analgesic requirements reported in the literature had not been studied. ${ }^{12}$

Our study revealed that intraarticular clonidine $(150 \mathrm{mcg})$ with local anaesthetic bupivacaine $0.25 \%, 20 \mathrm{~mL}$ produced increased postoperative analgesia but less when compared to the intraarticular dexmedetomidine $(100 \mathrm{mcg}$ ) with $0.25 \%$ bupivacaine, $20 \mathrm{~mL}$. Ramunas Tamosiunas et $\mathrm{al}^{9}$ conducted a randomized trial to evaluate the efficacy of intraarticular $0.5 \%$, $20 \mathrm{~mL}$ bupivacaine and a compound of bupivacaine with clonidine for postoperative analgesia after arthroscopic knee surgery. They used clonidine in a dose of $1 \mathrm{mcg} / \mathrm{kg}$. They concluded that the compound of intraarticular bupivacaine and clonidine suppresses pain better than intraarticular injection of bupivacaine or use of usual systemic analgesics $(\mathrm{p}<0.05)$. In our study we used both clonidine $150 \mathrm{mcg}$ and morphine $2 \mathrm{mg}$ resulted in equivocal analgesia, whereas the combination failed to demonstrate an enhanced analgesic effect. Wanda Joshi et al have demonstrated that the analgesic effect of bupivacaine was enhanced by the addition of IA clonidine. ${ }^{11}$ Gentil et al were first investigators to study the analgesic effects of morphine and clonidine in humans when used alone and in combination after arthroscopic knee surgeries. ${ }^{10}$ In our study, we compared duration of postop analgesia of clonidine with dexmedetomidine. We also used clonidine in a dose of $150 \mathrm{mcg}$ in our study, but the dose of dexmedetomidine was $100 \mathrm{mcg}$. Wanda Joshi et al ${ }^{11}$ also showed addition of clonidine provided more effective analgesia. The analgesic effects of $\alpha 2$-adrenergic agonist could be mediated through supraspinal, spinal and peripheral action. ${ }^{13}$

In our study, the analgesic effect of intra-articular clonidine and dexmedetomidine appears mainly due to a direct local action. The mechanism of analgesic effects for intra-articular dexmedetomidine might be similar to those suggested for intra-articular clonidine. Clonidine may act on presynaptic $\alpha 2$-adrenergic receptors and inhibit the release of norepinephrine at peripheral afferent nociceptors. ${ }^{14}$ Clonidine has also been shown to provide a local anaesthetic effect, which inhibits the conduction of nerve signals through $\mathrm{C}$ and A $\delta$ fibers. ${ }^{15}$ and may stimulate the release of enkephalin-like substances at peripheral sites. ${ }^{16} \mathrm{Al}$-Metwalli et al study found that intra-articular dexmedetomidine enhanced postoperative analgesia after arthroscopic knee surgery with an increased time to first analgesic request and a decreased need for postoperative analgesia. ${ }^{6}$ The study conducted by S Paul et al, showed that intraarticular dexmedetomidine as an adjunct to ropivacaine in pts. undergoing arthroscopic knee surgery have improved quality and duration of postoperative analgesia. ${ }^{17}$

Arthroscopic knee surgery is commonly performed on day-case basis. However, postoperative pain may be an obstacle for discharge and early rehabilitation. Several analgesic strategies such as systemic medication, central or peripheral blocks and intra-articular drug administration have been used to control pain after arthroscopic knee surgery. ${ }^{18}$ However, none is free from limitations such as the need for special equipment and monitoring or the risk of complications that may delay discharge or cause re-admission. Although, the 
pain has been reported slight-to-moderate and of short duration, a review of 20 studies showed evidence for reduction in postoperative pain after intra-articular local anaesthesia following arthroscopic knee surgery. ${ }^{19}$ No adverse effects or toxicity attributable to the intra-articular administration of local anaesthetics were reported in this review. 20

\section{CONCLUSION}

In our study, we have observed that IA administration of dexmedetomidine $100 \mathrm{mcg}$ with bupivacaine produces more prolonged postoperative analgesia upto $24 \mathrm{hrs}$. with mean duration of analgesia being group $D(18.4 \pm 4.958)(p<0.05)$ and VAS score $\geq 3$ than IA administration of clonidine 150 mcg with bupivacaine group $\mathrm{C}$ with mean duration of analgesia being $15.1 \pm 2.712$ hrs. VAS score $\geq 3$ with low pain scores for dexmedetomidine after arthroscopic knee surgeries. So we recommend that dosage of dexmedetomidine $100 \mathrm{mcg}$ +bupivacaine $20 \mathrm{~mL} 0.25 \%$ or clonidine $150 \mathrm{mcg}+$ bupivacaine $20 \mathrm{~mL} 0.25 \%$ are optimum for alleviating severe pain of arthroscopic knee surgeries for initial $24 \mathrm{hrs}$. postoperatively without any side effects.

\section{ACKNOWLEDGEMENT}

Authors would like to thank all the participants of the study. Authors also acknowledge the immense help received from the scholars whose articles are cited and included in references of this manuscript. The authors are also grateful to authors, editors and publishers of all those articles, journals and books from where the literature for this article has been reviewed and discussed.

\section{REFERENCES}

1. Weale AE, Ackroyd CE, Mani GV, et al. Day-case or shortstay admission for arthroscopic knee surgery: a randomised controlled trial. Ann R Coll Surg Engl 1998;80(2):146-9.

2. McGrath B, Elgendy H, Chung F, et al. Thirty percent of patients have moderate to severe pain $24 \mathrm{hrs}$. after ambulatory surgery: a survey of 5,703 patients. Can J Anaesth 2004;51(9):886-91.

3. Pavlin DJ, Chen C, Penaloza DA, et al. A survey of pain and other symptoms that affect the recovery process after discharge from an ambulatory surgery unit. J Clin Anaesth 2004;16(3):200-6.

4. Samoladas EP, Chalidis B, Fotiadis H, et al. Intra-articular use of ropivacaine for the control of post knee arthroscopy pain. J Orthop Surg Res 2006;1:17.

5. Mondal P, Saudagar AH. Intra-articular fentanyl for analgesia following arthroscopic knee surgery. Indian J Anaesth 2002;46(2):107-10.

6. Al-Metwalli RR, Mowafi HA, Ismail SA, et al. Effect of intraarticular dexmedetomidine on postoperative analgesia after arthroscopic knee surgery. $\mathrm{Br} \mathrm{J}$ Anaesth 2008;101(3):395-9.
7. Gerlach AT, Dasta JF. Dexmedetomidine: an updated review. Ann Pharmacother 2007;41(2):245-52.

8. Huang R, Hertz L. Receptor subtype and dose dependence of dexmedetomidine-induced accumulation of [14C] glutamine in astrocytes suggests glial involvement in its hypnotic-sedative and anaesthetic-sparing effects. Brain Res 2000;873(2):297-301.

9. Tamosiunas R, Tarnauskaite-Augutiene A, TranaskaiteKeraitiene G, et al. Postoperative analgesia with intraarticular local anaesthetic bupivacaine and alpha 2agonist clonidine after arthroscopic knee surgery. Medicina (Kaunas) 2005;41(7):547-52.

10. Gentili M, Enel D, Szymskiewicz 0, et al. Postoperative analgesia by intraarticular clonidine neostigmine in patients undergoing knee arthroscopy. Reg Anaesth Pain Med 2001;26(4):342-7.

11. Joshi W, Reuben SS, Kilaru PR, et al. Postoperative analgesia for outpatient arthroscopic knee surgery with intraarticular clonidine and/or morphine. Anaesth Analg 2000;90(5):1102-6.

12. Aasbo V, Raeder JC, Grogaard B, et al. No additional analgesic effect of intra-articular morphine or bupivacaine compared with placebo after elective knee arthroscopy. Acta Anaesthesiol Scand 1996;40(5):585-8.

13. Ebert TJ, Hall JE, Barney JA, et al. The effect of increasing plasma concentration of dexmedetomidine in humans. Anaesthesiology 2000;93(2):382-94.

14. Gentili M, Juhel A, Bonnet F. Peripheral analgesic effect of intra-articular clonidine. Pain 1996;64(3):593-6.

15. Butterworth JF, Strichartz GR. The alpha 2-adrenargic agonists clonidine and guanfacine produce tonic and phasic block of conduction in rat sciatic nerve fibres. Anaesth Analg 1993;76(2):295-301.

16. Nakamura M, Ferreira SH. Peripheral analgesic action of clonidine: mediation by release of endogenous enkephalin like substances. Eur J Pharmacol 1988; 146 (2):223-8.

17. Paul S, Bhattacharjee DP, Ghosh H, et al. Efficacy of intraarticular dexmedetomidine for postoperative analgesia in arthroscopic knee surgery. Ceylon Medical Journal 2010;55(4):111-5.

18. Bondok RS, Abd El-Hady AM. Intra-articular magnesium is effective for postoperative analgesia in arthroscopic knee surgery. Br J Anaesth 2006;97(3):389-92.

19. Moiniche S, Mikkelsen S, Wetterslev J, et al. A systematic review of intra-articular local anaesthesia for postoperative pain relief after arthroscopic knee surgery. Reg Anaesth Pain Med 1999;24(5):430-7.

20. Convery PN, Milligan KR, Quinn P, et al. Efficacy and uptake of ropivacaine and bupivacaine after single intraarticular injection in the knee joint. British Journal of Anaesthesia 2001;87(4):570-6. 